\title{
Effect of Ozone Treatment on Toxocara canis Eggs
}

\author{
Hong-Kean OOI, Ching-Lung LIN and Jiunn-Shiow WANG \\ Department of Veterinary Medicine, National Chung Hsing University, Taichung, Taiwan
}

(Received 17 July 1997/Accepted 18 September 1997)

\begin{abstract}
The effect of ozone treatment on the development and viability of Toxocara canis eggs was studied. Despite treatment with ozone, unembryonated $T$. canis eggs could develop into viable second-stage larvae when assayed by larvae recovery after oral inoculation into mice. The viability of second stage larvae of $T$. canis was also not affected by ozone treatment. No significant difference was observed in the larvae recovery count and migratory pattern of the ozone-treated larvae and the untreated control because the majority of the larvae were recovered from the liver and lungs on day 2 postinoculation. However, scanning electron microscopy of the ozone treated $T$. canis eggs showed many blebs on the surface of the protein coat at the basement of the honeycomb-like structures. The honeycomblike structures on the egg surface were also observed to be distorted after ozone treatment. Thus, in spite of inducing some surface morphological changes on the egg, ozone was observed to have no effect on the viability of the embryonated second stage larvae of $T$. canis. - KEY wORDS: egg, larvae viability, ozone, scanning electron microscopy, Toxocara canis.
\end{abstract}

J. Vet. Med.Sci. 60(2): 169-173, 1998

Ozone $\left(\mathrm{O}_{3}\right)$ is a dimagnetic molecule which is made up of three oxygen atoms. With a redox potential of $2.07 \mathrm{volt}$, it is one of the most potent oxidants available for the oxidation of water. It is widely used in water purification, neutralizing toxic chemical waste produced by industry, aquaculture, odor removal, increasing shelf life of foods and for sterilizing a variety of foods and swimming pools [17]. In addition, ozone has also been used to turn cyanide waste into harmless product during electroplating [16].

In aquaculture, ozone in conjunction with ultraviolet light, has been used to disinfect seawater for culturing clams and oyster [3] and also to remove bacteria from seawater [18]. The primary target in sterilization using ozone are bacteria, viruses and protozoa in food and drinking water. Although the ozone technology has been widely used, basic data on its effects on helminth eggs as well as its application in veterinary and medical parasitology are lacking. Only the zoonotic water-borne protozoa such as Giardia spp. [22, 24], Naegleria spp. [5], Acanthomoeba spp. [5] and Cryptosporidium [10,12] had been subjected to in-depth ozone testing. For helminth, the effect of ozone on only Schistosoma mansoni egg had been reported [11].

The objective of this study is to evaluate if ozone can destroy or inhibit the development of Toxocara canis eggs and its embryonated second stage larvae. Eggs of T. canis were treated with different concentration of ozone and then assayed for their viability in rodents. Changes in the morphological structures of the eggs after ozone treatment were also examined by scanning electron microscopy.

\section{MATERIALS AND METHODS}

$T$. canis eggs: Adult female worms of $T$. canis were obtained from puppies and infected dogs. Eggs were isolated by squashing the lower one-third of the uterus of adult female worms through a metallic filter mesh. The filtrate was treated with $10 \%$ sodium hypochlorite solution for $10 \mathrm{~min}$ to remove the mucus and then diluted with saline. After washing by successive centrifugations at 1,500 rpm in more than three changes of saline, a portion of the eggs was incubated in a conical flask in a solution containing $0.5 \%$ formaldehyde at $27^{\circ} \mathrm{C}$ for three weeks. The development of the embryo to the second stage larva was confirmed by examining a sample of the eggs under light microscope. These embryonated eggs were then treated with ozone followed by oral inoculation into mice.

The other portion of the unembryonated eggs were first treated with ozone, followed by culturing in $0.5 \%$ formaldehyde until they develop to second stage larvae, and then orally inoculated into mice.

For ozone treatment, aliquots of 20,000 eggs in oxygendemand-free deionized water were treated in a steady stream of ozone being generated at $3 \mathrm{l} / \mathrm{min}$ by an ozone generator, model RXO-5 (Ozoair, San Francisco, U.S.A.). The amount of ozone exposed to the eggs was adjusted by varying the time of exposure and the residual ozone was measured using the Indigo calorimetric method. Eggs were exposed to ozone for either 20 or $40 \mathrm{~min}$ and then immediately washed by diluting with deionized water followed by centrifugation. In a separate experiment to determine the initial ozone concentration using the same ozone generator machine and under almost similar condition, we found that the treated solution had residual ozone concentration of 3.86, 3.86, 4.38 and $4.62 \mathrm{mg} / \mathrm{l}$ of ozone after $0.5,1.0,1.5$ and $2 \mathrm{~min}$ of treatment, respectively.

Mice: Groups of three 6 to 8-week-old male outbred ICR mice (National Laboratory Animal Breeding and Research Center, [NLABRC] Taipei, Taiwan), which were given commercial feed pellet (Autoclavable Mouse 9f Diet, NLABRC) and water ad libitum, were orally inoculated with ozone-treated eggs which had been cultured until embryonated with second stage larvae or ozone-treated second stage larvae-containing eggs at a dose of 2,000 eggs per mouse. A group of three mice inoculated with second 
stage larvae containing eggs not treated with ozone was used as control.

All the mice were killed at $48 \mathrm{hr}$ postinoculation under ethyl ether anesthesia, and their livers, lungs and digestive tracts were removed separately. The digestive tract was further divided into four portions; the stomach, anterior and posterior half of the small intestine, and cecum-colon. The livers and lungs were digested in a solution containing $0.5 \%$ $(\mathrm{w} / \mathrm{v})$ pepsin in saline and its $\mathrm{pH}$ brought down to 2 or less by the addition of concentrated hydrochloric acid. Digestion was carried out under constant stirring using a magnetic stirrer in an incubator set at $37^{\circ} \mathrm{C}$ for $3 \mathrm{hr}$. The digesting solution were then allowed to stand followed by examining the sediment for larvae under a dissection microscope.

The digestive tracts were left to autolyse at $4^{\circ} \mathrm{C}$ for 3 days. They were slit open in a petri dish containing saline by macerating with optical forceps, followed by pipetting of the sample emulsion to dislodge the larvae from the tissues. Larval counts were then made under a dissection microscope.

Determination of aqueous ozone concentration: The concentration of ozone being exposed to the T. canis eggs was determined by the Indigo colorimetric method [2, 4]. Briefly, an indigo stock solution was made by dissolving $770 \mathrm{mg}$ of potassium indigo trisulfonate (Aldrich Chem. Co., Milwaukee, WI, U.S.A.) in $500 \mathrm{ml}$ of distilled water containing $1 \mathrm{ml}$ of concentrated phosphoric acid and the final volume brought up to $1,000 \mathrm{~m} l$ with distilled water. The indigo working solution was made by adding $10 \mathrm{~g}$ of sodium dihydrogen phosphate $\left(\mathrm{NaH}_{2} \mathrm{PO}_{4}\right)$ and $7 \mathrm{ml}$ of concentrated phosphoric acid to $100 \mathrm{ml}$ of indigo stock solution and bringing it up to $1,000 \mathrm{~m} l$ with distilled water.

For measuring the residual ozone, $5 \mathrm{ml}$ of the test sample was added to $10 \mathrm{~m} l$ of the indigo working solution in a 100 $\mathrm{m} l$ volumetric flask and the total volume brought up to 100 $\mathrm{m} l$ with distilled water. The blue colored solution was then measured spectrophotometrically at a wavelength of 600 $\mathrm{nm}$ using a Hitachi U-1100 spectrophotometer. Increase in residual ozone is indicated by decrease of the absorbance due to decolorization of the solution. Supernatant of the solution containing eggs not treated with ozone was used as control. Residual aqueous ozone concentration is expressed by the following equation:

where:

$$
\mathrm{mg} \mathrm{O}_{3} / \text { liter }=(100 \times d \mathrm{~A}) /(\mathrm{f} \times \mathrm{b} \times \mathrm{v})
$$

$d \mathrm{~A}=$ difference in absorbance between sample and blank,

$\mathrm{f}=0.42$ which is an absorption coefficient for aqueous ozone,

$\mathrm{b}=$ path length of cell, $\mathrm{cm}$, and

$\mathrm{v}=$ volume of sample, $\mathrm{m} l$.

Scanning electron microscopy: For scanning electron microscopy, both ozone treated and non-treated $T$. canis eggs were washed 3 times with saline and fixed in $2 \%$ glutaraldehyde in phosphate buffer, $\mathrm{pH} 7.4$, at $4{ }^{\circ} \mathrm{C}$ overnight. After washing with phosphate buffer, the eggs were then post-fixed in $2 \%(\mathrm{w} / \mathrm{v})$ osmium tetroxide in phosphate buffer for $2 \mathrm{hr}$ at $4^{\circ} \mathrm{C}$. The eggs were then washed again in phosphate buffer and dehydrated in an ascending series of alcohol for $15 \mathrm{~min}$ in each step and then transferred into isoamyl acetate. Thereafter, the eggs were dried in a carbon dioxide critical point dryer followed by mounting on a double sided tape, ion-coated with gold and then examined under a Hitachi S-410 scanning electron microscope.

Statistical analysis: Student's $t$-test was used to analyse the number of larvae recovered from the mice. The data were considered statistically significant if the $t$ value was above the $1 \%$ level.

\section{RESULTS}

No difference in the rate of development into second stage larvae of $T$. canis between ozone-treated and nontreated unembryonated eggs was observed. The recovery of T. canis larvae from the digestive tracts, livers and lungs of mice orally inoculated with cultured second stage larvae which were treated with ozone when still being unembryonated eggs, is shown in Table 1. The residual ozone shown in Table 1 was calculated with reference to the negative control. No significant difference $(p>0.01)$ in the number of larvae recovered between the ozone treated and the non-treated groups was observed.

The recovery of $T$. canis larvae from the digestive tracts, livers and lungs of mice orally inoculated with ozone-treated and non-treated second stage larvae, is shown in Table 2. No significant difference $(\mathrm{p}>0.01)$ in the number of larvae recovered between the ozone treated and the non-treated groups was observed. Thus treatment with ozone did not reduce or inhibit the migration of $T$. canis larvae in mice.

Table 1. Recovery of larvae from groups of three male ICR mice 2 days after inoculation with 2000 T. canis larvae which were cultured from ozone-treated eggs

\begin{tabular}{cccrc}
\hline $\begin{array}{c}\mathrm{O}_{3} \text { treatment } \\
\text { time }(\mathrm{min})\end{array}$ & $\begin{array}{c}\text { Residual } \\
\mathrm{O}_{3}(\mathrm{mg} / l)^{\mathrm{a})}\end{array}$ & $\begin{array}{l}\text { Digestive } \\
\text { tract }\end{array}$ & \multicolumn{1}{l}{ Liver } & \multicolumn{1}{c}{ Lungs } \\
\hline 0 & 0 & $\left.1.25 \pm 0.4^{\mathrm{b}}\right)$ & $1213 \pm 77.9$ & $17.3 \pm 7.7$ \\
20 & 5.91 & $1.75 \pm 0.8$ & $962.7 \pm 153.2$ & $2.7 \pm 2.5$ \\
40 & 6.76 & $2.4 \pm 2.2$ & $1184 \pm 215.9$ & $8 \pm 0$ \\
\hline
\end{tabular}

a) Measured concentration minus the concentration of the control b) Mean \pm S.D.

Table 2. Recovery of larvae from groups of three male ICR mice 2 days after inoculation with $2000 \mathrm{~T}$. canis larvated eggs which were treated with ozone

\begin{tabular}{ccccc}
\hline $\begin{array}{c}\mathrm{O}_{3} \text { treatment } \\
\text { time }(\min )\end{array}$ & $\begin{array}{c}\text { Residual } \\
\mathrm{O}_{3}(\mathrm{mg} / l)^{\mathrm{a})}\end{array}$ & $\begin{array}{c}\text { Digestive } \\
\text { tract }\end{array}$ & Liver & Lungs \\
\hline 0 & 0 & $8.5 \pm 7.9^{\mathrm{b})}$ & $1093 \pm 445.1$ & $11.7 \pm 11.1$ \\
20 & 5.24 & $11 \pm 11.3$ & $1277 \pm 420.1$ & $5 \pm 2.8$ \\
40 & 6.24 & $13.5 \pm 5$ & $1352 \pm 147.9$ & $16 \pm 4.1$ \\
\hline
\end{tabular}

a) Measured concentration minus the concentration of the control b) Mean \pm S.D. 
Scanning electron micrographs of embryonated eggs which was not treated with ozone is shown in Figs. 1, 2, those being treated with zone for 20 and 40 min, in Figs. 3, 4 and 5, 6, respectively. Figs. 1, 3, 5 were observed at 750 magnification and Figs. 2, 4, 6, at 5,000 magnification. At lower magnification, no apparent difference could be observed among the eggs. However, at higher magnification, the eggs treated with ozone showed flattened ridges of the surface honeycomb structure as compared with the non-treated control eggs. Moreover, T. canis eggs treated with 40 min of ozone showed many more "blebs" on the surface coat at the basement of the honeycomb-like structures than those eggs treated with ozone for $20 \mathrm{~min}$. Such "blebs" were not very conspicuous on eggs not treated with ozone.

\section{DISCUSSION}

Contamination of sandpits in pubic parks by $T$. canis eggs has been implicated as a public health problem in many countries, including Japan [19]. Since T. canis is known to cause visceral larva migrans in humans and in animals, many studies on various methods of sterilization for its infective embryonated eggs had been reported. These include maintaining partial dessication of sandpit by covering it with vinyl sheet [20], use of steam to disinfect sandpits [21], use of radiation such as X-ray and gamma ray [8], and also use of chemical such as benzalkonium-ion intercalated aluminium triphosphate [1]. The present study explored the use of ozone as a method of sterilization for T. canis eggs. The use of ozone for sterilization is worth considering because it is composed of only oxygen and will always decomposed into oxygen, and thus the question of polluting our environment or leaving a residual pollutant does not arise.

Our results showed that ozone alone has no apparent ovicidal nor larvicidal effects on $T$. canis as demonstrated by the lack of significant difference in larvae recovery from the experimentally infected mice. However, scanning electron microscopy of the ozone treated $T$. canis eggs showed alteration of its surface structure. Thus, it might be worth examining if ozone in combination with other agents, be it chemical or physical which when exposed alone might not have an ovicidal effect, may give rise to a strong synergistic ovicidal effect.

Ozone has been reported to be effective in inactivating cysts of Giardia lamblia [6, 22, 24], Naegleria gruberi [23], oocysts of Cryptosporidium parvum [10, 12] and Acanthamoeba culbertsoni [5]. The discrepancy in the effect of ozone seen in the present study may be due to the fact that the subject of our testing is a helminth egg, which is basically different from the cyst or oocyst of a single cell protozoan. Nevertheless, Mercado-Burgos et al. [11] reported that none of the snail used in the bioassay was observed to shed Schistosoma mansoni cercariae after being exposed to ova which had been treated with $40 \mathrm{mg} / \mathrm{l}$ of ozone. However, they cautioned that some of the ova might have survived the ozone treatment but the surviving miracidia might not have infected the snail for one reason or another. We have to note that $T$. canis eggs are resistant to formalin solution whereas $S$. mansoni eggs are not, and the miracidium can be easily dislodged through the operculum of the trematode egg.

The mechanism of ozone inactivation of virus has been implicated as first the alteration of the protein coat or capsid and subsequent damage in the viral nucleic acid itself [9, 13-15]. Similarly, ozone had been reported to penetrate the cell membrane of bacteria and causing disruption of chromosomal DNA [7]. Moreover, it is also known that inactivation of bacteria by ozone is by the oxidation of sulfhydrylic groups of their protoplasmic protein. It is possible that in our study, despite oxidation of the protein coat by ozone, the resulting complex may still be stable enough to prevent the total disintegration of the $T$. canis egg. However, the formation of the "blebs" on the surface coat at the basement of the honeycomb-like structures of those eggs treated with ozone for $40 \mathrm{~min}$ might have been the result of the oxidative process but further study will be needed to clarify this postulation.

In our experiment, sodium hypochlorite was used to remove the mucous content during the isolation of the $T$. canis eggs. Apparently, this did not morphologically alter the appearance of the surface protein layer as observed by scanning electron microscopy.

ACKNOWLEDGMENT. This work was supported by grant NSC86-2313-B-005-066 from the National Science Council, Taiwan.

\section{REFERENCES}

1. Akao, N., Tsukidate, S., Kondo, K. and Fujita, K. 1995. In vitro effects of benzalkonium-ion intercalated aluminium triphosphate on the second-stage larvae and fertilized eggs of Toxocara canis. Jpn. J. Parasitol. 44: 138-142.

2. Bader, H. and Hoigne, J. 1981. Determination of ozone in water by the indigo method. Water Res. 15:449-456.

3. Burkhardt, W., Rippey, S. R. and Watkins, W. D. 1992. Depuration rates of northern quahogs, Mercenaria mercenaria (Linnaeus, 1758) and eastern oysters Crassostrea virginica (Gmelin, 1791) in ozone- and ultraviolet-disinfected seawater systems. J. Shellfish Res. 11: 105-109.

4. Clesceri, L. S., Greenberg, A. E. and Trussell, R. R. 1989. Standard methods for the examination of water and wastewater, 17th edn., Publ. by American Public Health Association, American Water Works Association and Water Pollution Control Federation, Washington D. C., 4-162 to 4-165.

5. Cursons, R. T. M., Brown, T. J. and Keys, E. A. 1980. Effect of disinfectants on pathogenic free-living amoeba in axenic conditions. Appl. Environ. Microbiol. 40: 62-66.

6. Finch, G. R., Black, E. K., Labatiuk, C. W., Gyurek, L. and Belosevic, M. 1993. Comparison of Giardia lamblia and Giardia muris cyst inactivation by ozone. Appl. Environ. Microbiol. 59: 3674-3680.

7. Ishizaki, K., Sawadaishi, K., Miura, K. and Shinriki, N. 1987. Effect of ozone on plasmid DNA of Escherichia coli in situ. 

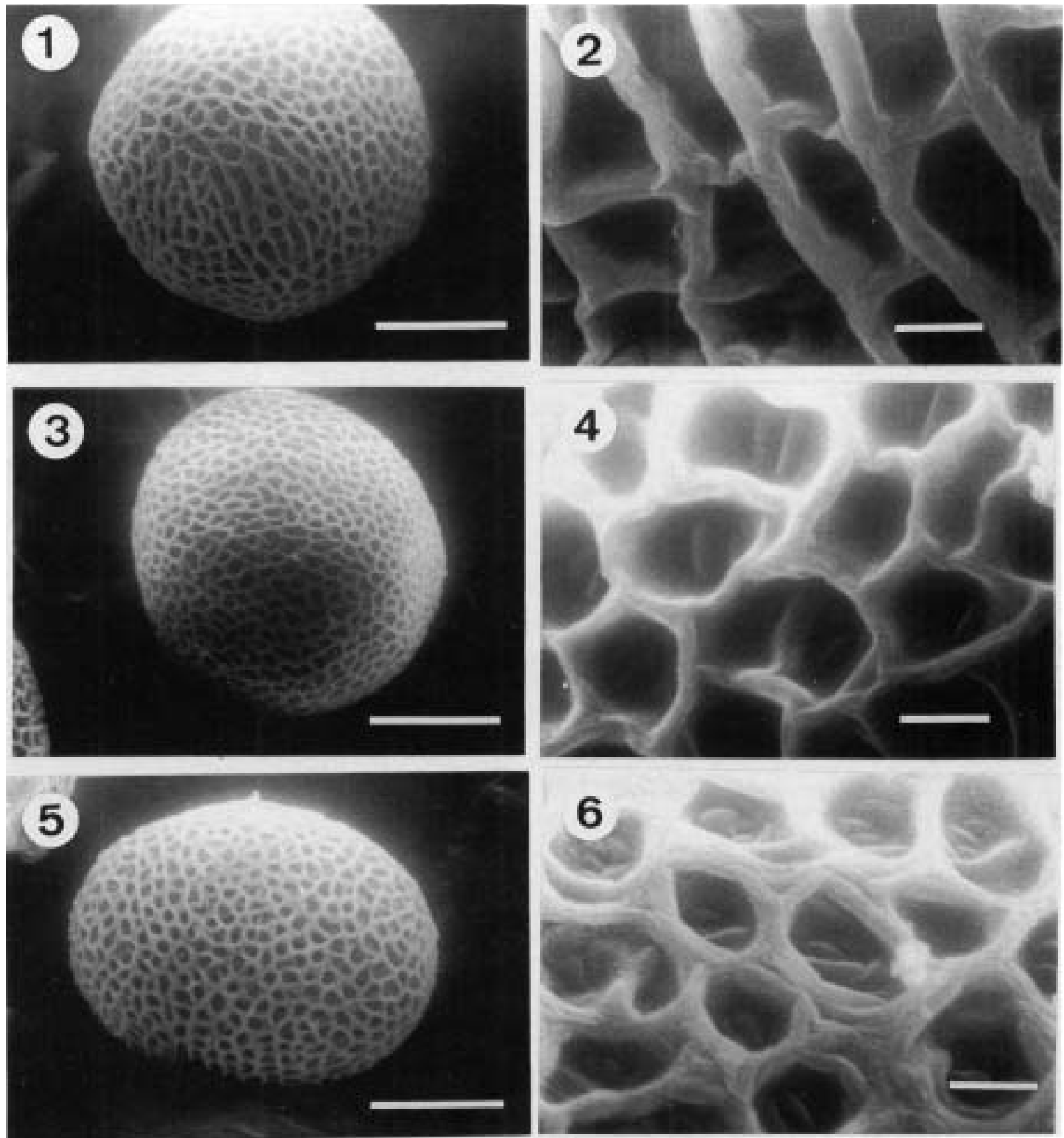

Scanning electron micrographs of Toxocara canis eggs

Fig. 1. T. canis egg which was not treated with ozone. $\times 750$. Bar $=30 \mu \mathrm{m}$.

Fig. 2. T. canis egg which was not treated with ozone. $\times 5,000$. Bar $=3 \mu \mathrm{m}$.

Fig. 3. T. canis egg which was treated with ozone for $20 \mathrm{~min}$. $\times 750$. Bar=30 $\mu \mathrm{m}$.

Fig. 4. T. canis egg which was treated with ozone for $20 \mathrm{~min} . \times 5,000$. Bar $=3 \mu \mathrm{m}$.

Fig. 5. T. canis egg which was treated with ozone for $40 \mathrm{~min} . \times 750$. Bar=30 $\mu \mathrm{m}$.

Fig. 6. T. canis egg which was treated with ozone for $40 \mathrm{~min} . \times 5,000$. Bar=3 $\mu \mathrm{m}$.

Water Res. 21: 823-827.

8. Kamiya, M., Ooi, H. K. and Nomura, T. 1987. The effect of radiation on the viability and migratory ability of secondstage larvae of Toxocara canis. Vet. Parasitol. 24: 87-92.

9. Kim, C. K., Gentile, D. M. and Sproul, O. J. 1980. Mecha- nism of ozone inactivation of bacteriophage f2. Appl. Environ. Microbiol. 39: 210-218.

10. Korich, D. G., Mead, J. R., Madore, M. S., Sinclair, N. A. and Sterling, C. R. 1990. Effect of ozone, chlorine dioxide, chlorine and monochloramine on Cryptosporidium parvum 
oocyst viability. Appl. Environ. Microbiol. 56: 1423-1428.

11. Mercado-Burgos, N., Hoehn, R. C. and Holliman, R. B. 1975. Effect of halogen and ozone on Schistosoma ova. J. Water Pollut. Cont. Fed. 47: 2411-2419.

12. Peeters, J. E., Mazas, E. A., Masschelein, W. J., Martinez de Maturana, I. V. and Debacker, E. 1989. Effect of disinfection of drinking water with ozone or chlorine dioxide on survival of Cryptosporidium parvum oocysts. Appl. Environ. Microbiol. 56: $1423-1428$.

13. Roy, D., Wong, P. K. Y., Engelbrecht, R. S. and Chian, E. S. K. 1981. Mechanism of enteroviral inactivation by ozone. Appl. Environ. Microbiol. 41: 718-723.

14. Shinriki, N., Ishizaki, K., Yoshizaki, T., Miura, K. and Ueda, T. 1988. Mechanism of inactivation of tobacco mosaic virus with ozone. Water Res. 22: 933-938.

15. Sproul, O. J., Pfister, R. M. and Kim, C. K. 1982. The mechanism of ozone inactivation of water borne viruses. $W a$ ter Sci. Technol. 14: 303-314.

16. Stopka, K. 1980. Advanced ozone technology for cyanide destruction in electroplating. Plating and Surface Finishing, (May) 1980: 77-80.

17. Stopka, K. 1989. Ozone's impact on drinking water, ultrapure water, cooling tower. Water Cond. Purification. 31: 38-40.
18. Sugita, H., Asai, T., Hayashi, K., Mitsuya, T., Amanuma, K., Maruyama, C. and Deguchi, Y. 1992. Application of ozone disinfection to remove Enterococcus seriolicida, Pastuerella piscicida and Vibrio anguillarum from seawater. Appl. Environ. Microbiol. 58: 4072-4075.

19. Uga, S. 1993. Prevalence of Toxocara eggs and number of faecal deposits from dogs and cats in sandpits of public parks in Japan. J. Helminthol. 67: 78-62.

20. Uga, S. and Kataoka, N. 1995. Measures to control Toxocara egg contamination in sandpits of public parks. Am. J. Trop. Med. Hyg. 52: 21-24.

21. van Knapen, F. and Franchimont, J. H. 1979. Steam sterilisation of sandpits infected with Toxocara eggs. Br. Med. J. 1: 1320.

22. Wickramanayake, G. B., Rubin, A. J. and Sproul, O. J. 1985. Inactivation of Giardia lamblia cysts with ozone. Appl. Environ. Microbiol 48: 671-672.

23. Wickramanayake, G. B., Rubin, A. J. and Sproul, O. J. 1985. Inactivation of Naegleria and Giardia cysts in water by ozonation. J. Water Pollut. Cont. Fed. 56: 983-988.

24. Wickramanayake, G. B., Rubin, A. J. and Sproul, O. J. 1985. Effect of ozone and storage temperature on Giardia cysts. $J$. Am. Water Works Assoc. 77: 74-77. 